\title{
Early childhood traffic-related air pollution and risk of allergic rhinitis at 2-4 years of age modification by family stress and male gender: a case-control study in Shenyang, China
}

Shuai Hao ${ }^{*}$, Fang Yuan, Pai Pang, Bo Yang, Xuejun Jiang and Aihui Yan*

\begin{abstract}
Background: Few studies have explored the modifications by family stress and male gender in the relationship between early exposure to traffic-related air pollution (TRAP) and allergic rhinitis (AR) risk in preschool children.

Methods: We conducted a case-control study of 388 children aged 2-4 years in Shenyang, China. These children AR were diagnosed by clinicians. By using measured concentrations from monitoring stations, we estimated the exposures of particulate matter less than $10 \mu \mathrm{m}$ in diameter $\left(\mathrm{PM}_{10}\right)$, nitrogen dioxide $\left(\mathrm{NO}_{2}\right)$, ozone $\left(\mathrm{O}_{3}\right)$, carbon monoxide (CO), and sulfur dioxide $\left(\mathrm{SO}_{2}\right)$ in preschool children aged 2-4 years. After adjusted potential confounding factors, we used logistic regression model to evaluate the odds ratio (OR) and $95 \%$ confidence interval (Cl) for childhood AR with exposure to different air pollutants according to the increasing of the interquartile range (IQR) in the exposure level.

Results: The prevalence of AR in children aged 2-4 years (6.4\%) was related to early TRAP exposure. With an IQR $\left(20 \mu \mathrm{g} / \mathrm{m}^{3}\right)$ increase in $\mathrm{PM}_{10}$ levels, an adjusted OR was significantly elevated by 1.70 (95\% Cl, 1.19 to 2.66). Also, with an IQR $\left(18 \mathrm{\mu g} / \mathrm{m}^{3}\right)$ increase in $\mathrm{NO}_{2}$, an elevated adjusted $\mathrm{OR}$ was 1.85 (95\% Cl, 1.52 to 3.18). Among children with family stress and boys, $\mathrm{PM}_{10}$ and $\mathrm{NO}_{2}$ were positively related to AR symptoms. No significant association was found among children without family stress and girls.
\end{abstract}

Conclusions: Family stress and male gender may increase the risk of AR in preschool children with early exposure to $\mathrm{PM}_{10}$ and $\mathrm{NO}_{2}$.

Keywords: Air pollution, Allergic rhinitis, Preschool children

*Correspondence: kellya@163.com; yah567@sina.com

Department of Otolaryngology, First Affiliated Hospital of China Medical University, No. 155, Nanjing North Street, Heping District, Shenyang 110001, China

C The Author(s). 2021 Open Access This article is licensed under a Creative Commons Attribution 4.0 International License, which permits use, sharing, adaptation, distribution and reproduction in any medium or format, as long as you give appropriate credit to the original author(s) and the source, provide a link to the Creative Commons licence, and indicate if changes were made. The images or other third party material in this article are included in the article's Creative Commons licence, unless indicated otherwise in a credit line to the material. If material is not included in the article's Creative Commons licence and your intended use is not permitted by statutory regulation or exceeds the permitted use, you will need to obtain permission directly from the copyright holder. To view a copy of this licence, visit http://creativecommons.org/licenses/by/4.0/ The Creative Commons Public Domain Dedication waiver (http://creativecommons.org/publicdomain/zero/1.0/) applies to the data made available in this article, unless otherwise stated in a credit line to the data. 


\section{Background}

Allergic rhinitis (AR) is the most common chronic allergic disease, involving inflammation of nasal eosinophils caused by air allergen sensitized by IgE [1]. AR is also considered a global health problem. Recently, the prevalence and incidence of AR have been increasing worldwide, especially in developing countries $[2,3]$. AR will not cause very serious damage to the body, and preschool children cannot clearly express their condition. Therefore, children with AR are easy to be ignored, especially for some Chinese children [3]. If AR continues to develop, it will cause more serious complications in the upper and lower respiratory tracts, including asthma and sinusitis [4], which will seriously affect the child's physical and social activities [5]. The etiology of AR is related to genetic and environmental risk factors. Since the rapid increase in the prevalence of AR in children is unlikely to be attributed solely to genetic changes, environmental factors have largely contributed to the development and deterioration of AR in China in the past decade [3]. Environmental factors include physical and social environmental exposure. However, there is little information about the potential effect modification of the social environment (family stress) on the relationship of children AR to the natural environment (traffic-related air pollution).

As a physical environmental factor, traffic-related air pollution (TRAP) can reduce lung function, cause asthma exacerbation, and lead to the development and exacerbation of allergic diseases, such as eczema, asthma, AR, and sensitization [6-8]. A meta-analysis showed that the prevalence of children AR increased with exposure to nitrogen dioxide $\left(\mathrm{NO}_{2}\right)$, sulfur dioxide $\left(\mathrm{SO}_{2}\right)$, and particulate matter $\left(\mathrm{PM}_{10}\right.$ and $\left.\mathrm{PM}_{2.5}\right)$, but the relationship between $\mathrm{SO}_{2} / \mathrm{PM}_{10}$ and prevalence of $\mathrm{AR}$ was not obviously closely in Asia [9]. Air pollutants come from many emission sources in cities, such as automobile exhaust, household oil fume, and industrial waste gas. In the past 10 years, the air pollution situation in Shenyang has changed. Motor vehicle traffic emissions are the main source of air pollution [10]. TRAP is the main source of changes in the concentration of air pollutants in cities [11]. A cohort study showed TRAP exposure during pregnancy and the first year of life was related to the development of AR in preschool children [3]. In addition, a case-control study showed that for residents less than $75 \mathrm{~m}$ from the main road increased lifetime diagnosis and AR symptoms of children aged 6 to 14 [12]. However, previous studies showed no significant correlation between TRAP exposure in early years of life and AR prevalence in children aged 1-12 years $[13,14]$. These inconsistencies in the epidemiological survey results are mainly due to differences in TRAP exposure assessment and the classification of the subgroups included. These studies assessed TRAP exposure through traffic measurements or modeling air pollutant concentrations, and most studies only considered the home address at birth [3, 12-14]. Furthermore, these studies included children aged 1-12 years and rarely included a narrow subgroup. Therefore, we need to limit the air exposure window of children with AR and the key components of air pollution in order to develop more effective prevention and intervention measures.

As a social environmental factor, psychological stress is related to allergic diseases including rhinitis, rhinoconjunctivitis, allergic conjunctivitis, wheezing, and asthma in children [15-18]. In recent years, little consideration has been given to the psychological impact of family stress on preschool children in China [19]. This is mainly because under the control of traditional Chinese culture, preschool children are unable or unwilling to express their feelings to their parents. Especially, in the face of stress, the depressive performance of parents will damage the entire family environment, thereby inhibiting the psychosocial functions of preschool children [20]. Family stress (including separation/divorce of parents, unemployment of parents, serious health problems, death of family members or close relatives) is a risk factor closely related to the occurrence or development of asthma [21, 22]. This may be due to being stimulated by antigen or stimulating immune cells in vitro [21, 23, 24]. However, few studies have explored the moderating effects of family stress and gender on the occurrence of AR in preschool children under TRAP. Therefore, this study aimed to evaluate whether preschool children are prone to develop AR during early-life TRAP exposure including $\mathrm{PM}_{10}, \mathrm{NO}_{2}$, ozone $\left(\mathrm{O}_{3}\right)$, carbon monoxide (CO), and $\mathrm{SO}_{2}$ exposures, with emphasis on stress or other possible influencing factors.

\section{Methods \\ Study design and participants}

We conducted a case-control study on TRAP-induced AR among preschool children aged 2-4 years in Shenyang, the capital of Liaoning Province in Northeast China. Liaoning province has a population of 8.32 million and an area of 12,948 $\mathrm{km}^{2}$. All protocols were approved by the medical ethics committee of China Medical University [approval number 2013-01-013]. Since 2013, we have carried out a long-term study of Children's respiratory health $(\mathrm{CRH})$ screening in Shenyang. These main data come from the cohort study $(\mathrm{CRH})$ for pregnant women at First Affiliated Hospital of China Medical University, from April 2013 to September 2014. The birth cohort included single births, full-term newborns, without deformities, and excluded infants whose mothers were younger than 20 years old and had alcohol or drug addiction. The data for this study came from Department 
of Obstetrics of the First Affiliated Hospital. We collected information about interviews with the mothers of each enrollee and telephone interviews with their parents when the children were 2,3 , and 4 years old. If the questionnaire showed AR symptoms, we invited these children to hospital for further diagnosis and free treatment. We determined the incidence of AR in preschool children in the birth cohort, and then their parents filled out the questionnaire when the children were 2, 3, and 4 years old. Every year, the professional doctors of our research group visited the parents of the included children by telephone to assess whether their children had AR in the one year before the diagnosis, and we recorded the data of TRAP exposure before the diagnosis of AR. We did not collect data that included children aged 1 year, because Chinese parents are reluctant to follow up their children by phone before their first birthday unless they have very obvious symptoms. In addition, the parents rarely paid attention to AR symptoms from birth to 2 years old, so we did not collect complete data. Thus, in this study, we selected children aged 0-2 years without AR symptoms, and calculated the average exposure level from 2 years of age to the day of AR diagnosis.

Here, the enrolled preschool children have always lived in their birthplace. From 2017 to 2018, we invited 5706 children aged 2-4 years and their mothers to participate in AR screening. These parents of enrolled children signed an information and consent form. The parents of the children participating in this study have read and signed the information and consent form before screening. Since the concentration of TRAP may decrease as the increase of building height, we excluded those children who lived above the fourth floor (about $8 \mathrm{~m}$ from the ground) [14]. In addition, in traditional Chinese families, most children go to kindergarten from the age of three. The resulting change in location (home and kindergarten) may increase personal contact errors. Therefore, we excluded those children whose homes were more than $400 \mathrm{~m}$ away from the kindergarten. In fact, we intended to make the air pollution of the children's home and kindergarten as same as possible. Since Chinese parents usually choose the kindergarten closest to their home [3], this situation can reduce the misclassification of personal contact.

In fact, we invited 5706 families (100\%) to participate in the survey, $1211(21.2 \%)$ families did not fill out the questionnaire, and $36(0.6 \%)$ families had hidden information. Then, 4459 families (78.2\%) completed the questionnaire and received the diagnosis. After that, a total of 3047 children's parents completed a symptom questionnaire about demographic information and daily life habits and received a diagnosis from a clinician. Moreover, these parents provided their children's information on the clinical symptoms of AR in the previous year ("In the past 12 months, did your child have a sneezing problem, or a runny or stuffy nose without a cold or flu?"). In addition, these parents also provided information about children with clinical symptoms of AR in the previous year ("In the past 1 year, did your children have a sneezing problem, or a runny nose or nasal congestion without a cold or flu?"). Other current socioeconomic factors were provided through the use of the Chinese revised version of "AR International Research in the children's standardized questionnaire".

In the end, we recruited 194 participants with AR (case group) and 194 participants without AR (control group) from 3047 children. The case group needs to be diagnosed by otolaryngologists and medical staff in accordance with the "Chinese AR Allergen Immunotherapy Guidelines", excluding children with asthma, atopic dermatitis, or allergic conjunctivitis [1]. The control group was randomly selected from other children $(n=2853)$, without allergic diseases (including allergic conjunctivitis, $\mathrm{AR}$, asthma, and atopic dermatitis), and matched with cases (1:1) by month. Air pollution exposure of the individual participants $(n=388)$ was estimated based on the measurement results of the municipal air monitoring stations, which was located about $1000 \mathrm{~m}$ from each participant's home, and these monitoring points in Shenyang are mainly located in major traffic near the roads. The relative distance between the participant's address and the location of the emission source affect the levels of air pollutants. We recorded the addresses of each child's home and kindergarten, and then selected the nearest monitoring station from the line between the family and the kindergarten to assess traffic air pollution exposure. If the relative distance exceeded $1000 \mathrm{~m}$, the average of five nearby monitoring stations was used as the representative value. In order to reduce the bias caused by the distance between the family and the kindergarten, we selected children whose family is within $400 \mathrm{~m}$ from the kindergarten. In addition, since this study only analyzed the existing data of indirect interaction with the subjects, this study complies with the principle of giving up informed consent.

\section{TRAP exposure}

According to the related epidemiological studies on TRAP and allergic diseases $[3,5]$, we selected five pollutants in Shenyang, namely $\mathrm{PM}_{10}$ (beta gauge method), $\mathrm{SO}_{2}$ (ultraviolet fluorescence method), $\mathrm{CO}$ (nondispersive infra-red absorption method), $\mathrm{NO}_{2}$ (chemiluminescence method), and $\mathrm{O}_{3}$ (ultraviolet absorption method) as TRAP markers [25]. According to the principle that errors will occur if the established statistical model contains highly correlated pollutants, and the pilot test also reflected that there was a high correlation between $\mathrm{PM}_{2.5}$ and $\mathrm{PM}_{10}(r=0.841)$, and $\mathrm{PM}_{2.5}$ are sub-elements of $\mathrm{PM}_{10}$. So $\mathrm{PM}_{2.5}$ was not chosen in this study. Based on the previous study [26], we calculated the average ambient 
concentrations of $\mathrm{PM}_{10}, \mathrm{O}_{3}, \mathrm{SO}_{2}, \mathrm{CO}$, and $\mathrm{NO}_{2}$. We obtained the average daily concentrations of these pollutants for each participant from 2015 to 2018, selected children between 0 (2013/2014) and 2 years old (2015/2016) without AR symptoms, and calculated the average daily concentrations of these pollutants for each child from 2 years old to the day of AR diagnosis. We recorded TRAP exposure from April 2015 to September 2018. The data came from air pollution monitoring station within $1000 \mathrm{~m}$ of each participant's residence. We recorded the daily average exposure of each child in usual residence and then calculated the monthly average concentration of the aggregate exposures. As for the exposure of $\mathrm{CO}$ and $\mathrm{O}_{3}$, we calculated the average 8-h concentration from these same monitors.

\section{Covariates and stress measure}

Through a survey of parents of enrolled children, we collected the characteristics of children (sex, birth weight, eczema, and feeding mode in the first year), the characteristics of parents (delivery mode, parents' allergy history: at least one parent has a history of AR, active and passive smoking), socioeconomic status of the family (address, pets, furniture, redecoration, and family stress including parental separation/divorce, parental unemployment, serious health problems, or the death of a family member or close relative). Children's chronic stress was obtained through the Life Stress Interview from UCLA [27].

\section{Statistical analysis}

We used Chi-square test to compare the frequencies in the baseline characteristics of two groups, used twosample $t$-test to compare the birth weight values of the two groups, and used Logistic regression model to evaluate the covariates increasing the correlation of TRAP and AR risk. If the covariate is significantly correlated with risk $(p<0.05)$, or the adjusted odds ratio (aOR) changes by more than $10 \%$, then the covariate is selected to enter the model analysis. To evaluate the existence of potential moderating effects, we used likelihood ratio test (LRT) to compare models with and without moderating variables in the conditional logistic regression model. If there is a significant level of LRT difference ( $p$ $<0.1$ ), it is considered that there is a moderating effect. Only family stress and male gender met this criterion, so only the stratified OR of these two moderating variables was shown. We used aOR and 95\% confidence interval $(95 \% \mathrm{CI})$ to express the relationship between TRAP and AR. The recorded TRAP levels were continuous variables. We used quartiles to represent the relationship between the increase in $\mathrm{PM}_{10}, \mathrm{SO}_{2}, \mathrm{NO}_{2}, \mathrm{CO}$, or $\mathrm{O}_{3}$ and AR. We chose exposure levels below the 25th percentile as the reference (baseline level) for each pollutant. Then, through the interquartile range (IQR), the continuous variables were changed to the categorical variables, and the linear correlation between the pollutant parameters was analyzed for the co-linearity test. The data were analyzed by SPSS software for Windows, version 20.0 (IBM SPSS, Inc., Chicago, IL, USA).

\section{Results \\ Participants}

Table 1 showed the natural characteristics and clinical diagnosis of 3047 children. Taking into account the living floor, the distance between the family and the kindergarten, we deleted $40 \%$ of the children $(n=2$, 659). Compared with the 2659 children who were not included in the study, the parents of 3047 children who were included were more likely to have a history of $\operatorname{AR}(p=0.01)$. There was no statistical differences in other demographic variables between the children who were not included and the children who were included in the study. Figure 1 was a flowchart of cases and controls selection.

Table 1 Baseline characteristics of children included $(n=3047)$ and not included $(n=2659)$

\begin{tabular}{llll}
\hline Baseline characteristics & Included $\boldsymbol{n}(\%)$ & Not included $\boldsymbol{n}$ (\%) & $\boldsymbol{p}$-value \\
\hline Male sex & $1569(51.5)$ & $1377(51.8)$ & 0.79 \\
Birth weight & $3.45 \pm 0.43$ & $3.45 \pm 0.47$ & 0.83 \\
Residence in city & $2163(71.0)$ & $1808(68.0)$ & 0.46 \\
Environmental smoke & $768(25.2)$ & $723(27.2)$ & 0.61 \\
Cesarean & $2142(70.3)$ & $1840(70.4)$ & $863(33.1)$ \\
Formula-feeding & $985(32.6)$ & $361(13.8)$ & 0.95 \\
Parental allergy & $703(23.1)$ & $606(23.2)$ & 0.64 \\
Pets & $693(23.0)$ & $195(7.7)$ & 0.01 \\
House redecoration & $250(8.4)$ & $541(21.1)$ & 0.92 \\
Stressful family & $605(20.3)$ & & 0.75 \\
\hline
\end{tabular}

Total numbers may not be equal to 3047 and 2659 for some characteristics due to missing data 


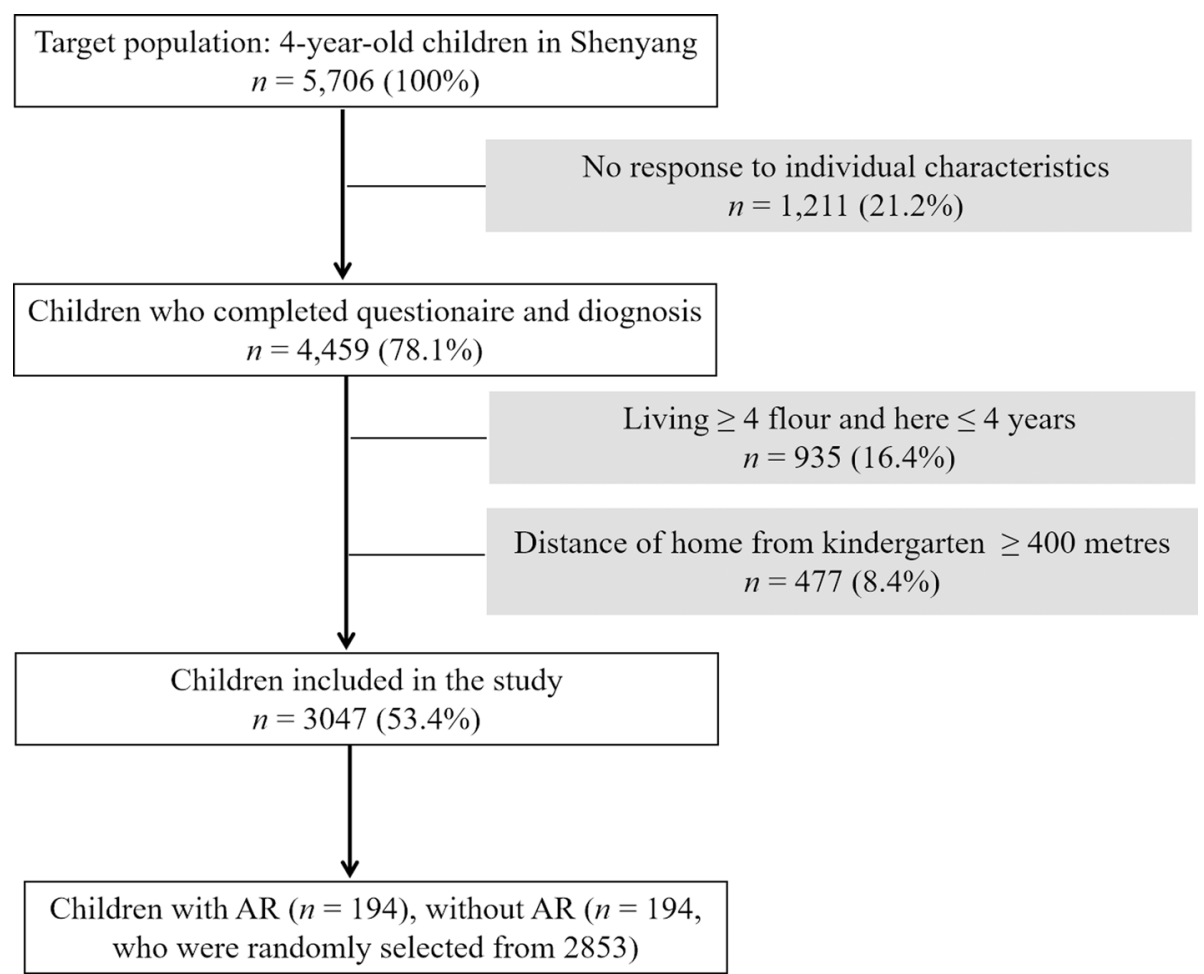

Fig. 1 The flow chart of cases and controls selection

$\mathrm{PM}_{10}, \mathrm{SO}_{2}, \mathrm{NO}_{2}, \mathrm{CO}$, and $\mathrm{O}_{3}$ levels

Table 2 showed the pollutants $\left(\mathrm{PM}_{10}, \mathrm{SO}_{2}, \mathrm{NO}_{2}, \mathrm{CO}\right.$, and $\mathrm{O}_{3}$ ) concentration distribution in the included children before AR diagnosis date. The concentration ranges of these pollutants $\left(\mathrm{PM}_{10}, \mathrm{SO}_{2}, \mathrm{NO}_{2}, \mathrm{CO}\right.$, and $\mathrm{O}_{3}$ ) were from 40 to $115 \mu \mathrm{g} / \mathrm{m}^{3}$ with a median (IQR) of $88(75-95) \mu \mathrm{g} / \mathrm{m}^{3}$, from 5 to $59 \mu \mathrm{g} / \mathrm{m}^{3}$ with a median of $26(20-34) \mu \mathrm{g} / \mathrm{m}^{3}$, from 12 to $60 \mu \mathrm{g} / \mathrm{m}^{3}$ with a median of $31(23-41) \mu \mathrm{g} / \mathrm{m}^{3}$, from 480 to $2380 \mu \mathrm{g} / \mathrm{m}^{3}$ with a median of $970(906-1260) \mu \mathrm{g} / \mathrm{m}^{3}$, and from 63 to 116 $\mu \mathrm{g} / \mathrm{m}^{3}$ with a median of $92(80-102) \mu \mathrm{g} / \mathrm{m}^{3}$, respectively.

\section{Main results}

Table 3 showed the distribution of sociodemographic characteristics of AR children compared to controls. The

Table 2 Distribution of ambient air pollution concentrations $\left(\mu \mathrm{g} / \mathrm{m}^{3}\right)$

\begin{tabular}{llllll}
\hline $\begin{array}{l}\text { Air } \\
\text { pollutant }\end{array}$ & Mean & \multicolumn{3}{l}{ Percentile distribution } & IQR \\
\cline { 3 - 5 } & & $\boldsymbol{P}_{\mathbf{2 5}}$ & $\boldsymbol{P}_{\mathbf{5 0}}$ & $\boldsymbol{P}_{\mathbf{7 5}}$ & \\
\hline $\mathrm{PM}_{10}$ & 88 & 75 & 88 & 95 & 20 \\
$\mathrm{SO}_{2}$ & 26 & 20 & 26 & 34 & 14 \\
$\mathrm{NO}_{2}$ & 31 & 23 & 31 & 41 & 18 \\
$\mathrm{CO}$ & 970 & 906 & 970 & 1260 & 354 \\
$\mathrm{O}_{3}$ & 92 & 80 & 92 & 102 & 22 \\
\hline
\end{tabular}

IQR interquartile range
6.4\% (194/3,047) among enrolled children aged 2-4 years was diagnosed by clinicians. There were statistical differences between cases and controls in the distributions of the following characteristics: percentage of boys ( $64 \%$ vs $48 \%$ ), city residence ( $83 \%$ vs $70 \%$ ), eczema in the first year after birth ( $57 \%$ vs $41 \%)$, parental allergy ( $31 \%$ vs $13 \%$ ), and family stress (50\% vs $18 \%$ ). There was no statistically significant difference in the distribution of other variables between cases and controls. Overall, the crude ORs for AR was 2.18 (95\% CI, 1.35 to 3.52) for children living in cities, 1.88 (95\% CI, 1.26 to 2.81) for boys, 1.91 ( $95 \% \mathrm{CI}, 1.28$ to 2.85 ) for children suffering from eczema in the first year after birth, 2.94 (95\% CI, 1.77 to 4.87) for children with a history of parental allergies, and 4.14 (95\% CI, 2.65 to 6.49) for children with family stress. There were no significant associations of AR with other variables, no co-linearity problems for TRAP and others parameters.

Table 4 showed the Spearman correlation coefficients of these pollutants $\left(\mathrm{PM}_{10}, \mathrm{SO}_{2}, \mathrm{NO}_{2}, \mathrm{CO}\right.$, and $\left.\mathrm{O}_{3}\right)$ concentrations before the diagnosis of AR. These values indicated that there was a moderate correlation between the average values of these pollutants.

Table 5 showed the estimated impact of pollutants $\left(\mathrm{PM}_{10}, \mathrm{SO}_{2}, \mathrm{NO}_{2}, \mathrm{CO}\right.$ and $\left.\mathrm{O}_{3}\right)$ on the occurrence of $\mathrm{AR}$ in preschool children with each additional IQR under single factor analysis. In the single-pollutant models, 
Table 3 Characteristics of children with or without allergic rhinitis $(n=388)$

\begin{tabular}{|c|c|c|c|c|c|}
\hline Characteristics $^{a}$ & Cases $(n=194), n(\%)$ & Controls $(n=194), n(\%)$ & Crude odds ratio $(95 \% \mathrm{Cl})$ & $x^{2}$ & $p$-value \\
\hline \multicolumn{6}{|l|}{ Sex } \\
\hline Girls & $70(36.1)$ & $101(52.1)$ & Reference & 9.557 & 0.002 \\
\hline Boys & $124(63.9)$ & $93(47.9)$ & $1.880(1.258,2.809)$ & & \\
\hline Birth weight & $3.53 \pm 0.59$ & $3.40 \pm 0.67$ & - & - & 0.844 \\
\hline \multicolumn{6}{|l|}{ Residence } \\
\hline Suburbs & $33(17.0)$ & $59(30.4)$ & Reference & 10.455 & 0.001 \\
\hline Inner city & $161(83.0)$ & $135(69.6)$ & $2.180(1.352,3.516)$ & & \\
\hline \multicolumn{6}{|c|}{ Environmental tobacco smoke at home } \\
\hline No & $142(73.2)$ & $151(77.8)$ & Reference & 0.567 & 0.452 \\
\hline Yes & $52(26.8)$ & $43(22.2)$ & $1.190(0.756,1.873)$ & & \\
\hline \multicolumn{6}{|l|}{ Mode of delivery } \\
\hline Vaginal delivery & $58(29.9)$ & $55(28.4)$ & Reference & 0.011 & 0.916 \\
\hline Elective cesarean section & $136(70.1)$ & $139(71.6)$ & $0.977(0.635,1.502)$ & & \\
\hline \multicolumn{6}{|c|}{ Mode of feeding in the first year } \\
\hline Breast-feeding & $129(66.5)$ & $133(68.6)$ & Reference & 0.060 & 0.807 \\
\hline Formula-feeding & $65(33.5)$ & $61(31.4)$ & $1.054(0.693,1.601)$ & & \\
\hline \multicolumn{6}{|l|}{ Eczema during the first year } \\
\hline No & $83(42.8)$ & $115(59.3)$ & Reference & 10.238 & 0.001 \\
\hline Yes & $111(57.2)$ & $79(40.7)$ & $1.910(1.283,2.845)$ & & \\
\hline \multicolumn{6}{|l|}{ Parental history of allergy } \\
\hline No & $134(69.1)$ & $171(88.1)$ & Reference & 18.223 & 0.000 \\
\hline Yes & $60(30.9)$ & $23(11.9)$ & $2.935(1.769,4.872)$ & & \\
\hline \multicolumn{6}{|l|}{ Furry/feathery pets } \\
\hline No & $150(77.3)$ & $151(77.8)$ & Reference & 0.040 & 0.841 \\
\hline Yes & $44(22.7)$ & $43(22.2)$ & $0.953(0.598,1.520)$ & & \\
\hline \multicolumn{6}{|l|}{ New furniture after birth } \\
\hline No & $98(50.5)$ & $103(53.1)$ & Reference & 0.234 & 0.628 \\
\hline Yes & $96(49.5)$ & $91(46.9)$ & $1.102(0.744,1.633)$ & & \\
\hline \multicolumn{6}{|c|}{ House redecoration during the past year } \\
\hline No & $171(88.1)$ & $180(92.8)$ & Reference & 2.334 & 0.127 \\
\hline Yes & $23(11.9)$ & $14(7.2)$ & $1.695(0.856,3.354)$ & & \\
\hline \multicolumn{6}{|c|}{ Stressful family events during the first 2 years ${ }^{b}$} \\
\hline No & $98(50.5)$ & $160(82.5)$ & Reference & 40.910 & 0.000 \\
\hline Yes & $96(49.5)$ & $34(17.5)$ & $4.144(2.647,6.489)$ & & \\
\hline
\end{tabular}

Data are shown as $n(\%)$ or mean \pm SD

${ }^{a}$ Characteristics are at birth unless otherwise specified

${ }^{b}$ Among parental separation/divorce, parental loss of job, serious health problem, or death of a family member or close relative

under the premise of adjusting for other influencing factors, AR was significantly correlated with $\mathrm{PM}_{10}$ and $\mathrm{NO}_{2}$ in preschool children, with aOR $=1.31(95 \% \mathrm{CI}, 1.08$ to $1.90)$ and 1.15 (95\% CI, 1.02 to 2.23$)$ respectively. Regardless of the single-pollutant models or the multipollutant models, AR was statistically related to $\mathrm{PM}_{10}$ and $\mathrm{NO}_{2}$. In the multi-pollutant models, the correlations between these pollutants $\left(\mathrm{PM}_{10}, \mathrm{NO}_{2}, \mathrm{O}_{3}\right.$, and $\left.\mathrm{CO}\right)$ and $\mathrm{AR}$ were enhanced, accompanied by a wider $\mathrm{CI}$ range.
Only the OR attenuation between $\mathrm{SO}_{2}$ and $\mathrm{AR}$ was close to the null value. Thus, the correlation between the pollutant $\left(\mathrm{PM}_{10}\right.$ or $\left.\mathrm{NO}_{2}\right)$ and $\mathrm{AR}$ was strong in preschool children, apart from affecting the changes in the effect estimation.

Table 6 showed the logistic regression of the relationship between AR and pollutants (an IQR increase in $\mathrm{PM}_{10}$ and $\mathrm{NO}_{2}$ ) was stratified by gender, eczema, heredity, or stress after other related variables were adjusted. 
Table 4 Spearman correlation coefficients for the estimates of ambient air pollutant concentrations

\begin{tabular}{llllll}
\hline Air pollutant & $\mathbf{P M}_{\mathbf{1 0}}$ & $\mathbf{S O}_{\mathbf{2}}$ & $\mathbf{N O}_{\mathbf{2}}$ & $\mathbf{C O}$ & $\mathbf{O}_{\mathbf{3}}$ \\
\hline $\mathrm{PM}_{10}$ & 1 & 0.442 & 0.463 & 0.413 & 0.165 \\
$\mathrm{SO}_{2}$ & & 1 & 0.339 & 0.452 & -0.282 \\
$\mathrm{NO}_{2}$ & & & 1 & 0.709 & -0.210 \\
$\mathrm{CO}$ & & & & 1 & -0.235 \\
$\mathrm{O}_{3}$ & & & & & 1 \\
\hline
\end{tabular}

The bases for stratification were based on the variables in Table 3 that had statistically different associations with AR. An IQR $\left(20 \mu \mathrm{g} / \mathrm{m}^{3}\right)$ increase in $\mathrm{PM}_{10}$ in boys was positively statistically associated with the risk of AR with $\mathrm{aOR}=1.46$ (95\% CI, 1.13 to 2.08$)$, and $1.76(95 \%$ CI, 1.10 to 3.11 ) among preschool children with stress, respectively. Moreover, an IQR $\left(18 \mu \mathrm{g} / \mathrm{m}^{3}\right)$ increase in $\mathrm{NO}_{2}$ in boys was positively statistically associated with the risk of $\mathrm{AR}$ with $\mathrm{aOR}=2.13$ (95\% CI, 1.31 to 3.45 ), and 1.94 (95\% CI, 1.18 to 3.20 ) among preschool children with stress.

Table 7 showed that family stress and male gender were two moderating variables that positively correlated pollutant exposure $\left(\mathrm{PM}_{10}, \mathrm{NO}_{2}\right)$ with the risk of $\mathrm{AR}$. In the single-pollutant model, these factors interacted on a multiplicative scale. Stratified by family pressure or gender, there was no dose-response relationship of the positive correlation between $\mathrm{PM}_{10}$ and the risk of AR. However, there was a dose-response relationship between $\mathrm{NO}_{2}$ and AR. In the single-pollutant models, family stress increased the positive correlation between pollutants $\left(\mathrm{PM}_{10}, \mathrm{NO}_{2}\right)$ and the risk of $\mathrm{AR}$, with 1.80 (95\% CI, 1.61 to 2.02 ) and 1.98 (95\% CI, 1.74 to 2.43 ) for the above 75 th percentile vs. below the 25th percentile of exposure, than among never family stress [1.07 (95\% CI, 0.86 to 1.36), 1.48 (95\% CI, 1.03 to 1.85 )], respectively. According to the

Table 5 Conditional logistic regression estimated adjusted odds ratios (ORs) and 95\% confidence intervals (Cls) for associations of allergic rhinitis with ambient air pollution exposure among children

\begin{tabular}{lll}
\hline & \multicolumn{1}{l}{ Single $^{a}$} & Multi $^{\boldsymbol{b}}$ \\
\hline PM10 & $1.31(1.08,1.90)^{*}$ & $1.70(1.19,2.66)^{*}$ \\
$\mathrm{SO} 2$ & $1.26(0.73,1.97)$ & $0.84(0.49,1.38)$ \\
$\mathrm{NO2}$ & $1.15(1.02,2.23)^{*}$ & $1.85(1.52,3.18)^{*}$ \\
$\mathrm{CO}$ & $1.13(0.77,2.02)$ & $1.15(0.64,2.39)$ \\
O3 & $0.52(0.23,1.02)$ & $0.60(0.31,1.08)$ \\
\hline
\end{tabular}

OR $(95 \% \mathrm{Cl})$ was estimated for an IQR increase in PM10, SO2, NO2, CO, and O3 ${ }^{*} p<0.05$

${ }^{* *} p<0.01$

${ }^{a}$ Single-pollutant model: adjustment for all the potential covariates in Table 2 including personal factors (sex, birth weight, delivery, feeding, eczema, parental allergy, and stress) and indoor factors (tobacco smoke, new furniture, pets, house redecoration)

${ }^{b}$ Multi-pollutant model: $\mathrm{PM}_{10}+\mathrm{SO}_{2}+\mathrm{NO}_{2}+\mathrm{CO}+\mathrm{O}_{3}$. Further adjustment for the effects of the other air pollutants on the base of single-pollutant model effect evaluation of LRT heterogeneity, there was statistical significance $(p=0.03,0.04)$. Also, boys increased the positive correlation between pollutants $\left(\mathrm{PM}_{10}, \mathrm{NO}_{2}\right)$ and AR, with 1.49 (95\% CI, 1.18 to 1.82 ) and 2.10 (95\% CI, 1.85 to 2.55 ) for the above 75 th percentile vs. below the 25th percentile of exposure, than among girls [1.11 (95\% CI, 0.93 to 1.42$)$ and 1.52 (95\% CI, 1.21 to 1.94$)$ ], respectively $(p=0.01,0.01)$.

\section{Discussion}

In this case-control study, we explored the moderating effects of family stress on the relationship between earlylife TRAP exposure and the risk of AR in preschool children. In the whole study population, $\mathrm{PM}_{10}$ or $\mathrm{NO}_{2}$ exposure was positively associated with the risk of AR in children aged 2-4 years, respectively. We also analyzed whether sex, parental allergy history, and eczema in the first year increased the risk of AR in preschool children, under $\mathrm{PM}_{10}$ or $\mathrm{NO}_{2}$ exposure. These factors were also positively correlated with AR. By exploring the potential moderating effects of numerous risk factors associated with AR (when a causal effect of intervening on one exposure, there was another variable stratification), we found that family stress or boys increased the risk of $\mathrm{PM}_{10}$ or $\mathrm{NO}_{2}$ exposure to AR.

The main findings of this study were to explore the relationship between early TRAP $\left(\mathrm{PM}_{10}\right.$ or $\left.\mathrm{NO}_{2}\right)$ exposure and the risk of AR in preschool children. Family stress and male gender may play a moderating effect on the relationship. Using the multi-pollutant model, the risks of other air pollutants to AR were adjusted to estimate their correlation. $\mathrm{PM}_{10}, \mathrm{SO}_{2}, \mathrm{NO}_{2}, \mathrm{CO}$, and $\mathrm{O}_{3}$ have been used as markers of traffic air pollution. We only found that preschool children exposed to $\mathrm{PM}_{10}$ and $\mathrm{NO}_{2}$ had an increased risk of AR by $70 \%$ and $85 \%$, respectively.

The prevalence of AR among middle-school students in Taiwan was related to the concentrations of nitrogen oxides (NOx) and $\mathrm{CO}$ exposures [25]. In China, atmospheric $\mathrm{CO}$ and $\mathrm{NO}_{2}$ are the emissions of automobile exhaust, which are caused by incomplete combustion inside motor engines [11]. We used a multi-pollutant model to evaluate the association between combined exposure $\left(\mathrm{PM}_{10}, \mathrm{O}_{3}, \mathrm{SO}_{2}, \mathrm{CO}\right.$ and $\left.\mathrm{NO}_{2}\right)$ and the risk of AR in children, instead of choosing $\mathrm{PM}_{2.5}$ as a marker of TRAP. Because $\mathrm{PM}_{2.5}$ is highly correlated with $\mathrm{PM}_{10}$, there may be some potential variance inflation and deviation [28, 29]. Since we did not know which model would cause the least bias in the estimation, we compared the results of the single-pollutant model and the multi-pollutant model. In most cases, in both models, the effect estimates show similar associations between exposure and dependent variables. And most of the effect estimates in the multi-pollutant model are higher than those in the single-pollutant model. This study 
Table 6 Association (adjusted odds ratios and 95\% confidence interval) between exposure and allergic rhinitis among children ( $n=$ 388), stratified by significant covariates

\begin{tabular}{|c|c|c|c|}
\hline & $n$ & $\begin{array}{l}\text { Effect per } 20 \mu \mathrm{g} / \mathrm{m}^{3} \text { of } \mathrm{PM}_{10} \\
\text { aOR }(95 \% \mathrm{Cl}), p \text {-value }\end{array}$ & $\begin{array}{l}\text { Effect per } 18 \mu \mathrm{g} / \mathrm{m}^{3} \text { of } \mathrm{NO}_{2} \\
\text { aOR }(95 \% \mathrm{Cl}), p \text {-value }\end{array}$ \\
\hline \multicolumn{4}{|c|}{ Stressful family events } \\
\hline No & 258 & $0.93(0.63,1.22)$ & $0.94(0.73,1.84)$ \\
\hline Yes & 130 & $1.76(1.10,3.11)^{*}, 0.028$ & $1.94(1.18,3.20)^{* *}, 0.009$ \\
\hline \multicolumn{4}{|c|}{ Parental history of allergy } \\
\hline No & 205 & $0.80(0.61,1.08)$ & $1.09(0.63,1.23)$ \\
\hline Yes & 83 & $1.08(0.95,1.34), 0.113$ & $1.46(1.00,2.26), 0.084$ \\
\hline \multicolumn{4}{|c|}{ Eczema during the first year } \\
\hline No & 198 & $0.76(0.49,1.20)$ & $0.91(0.28,1.85)$ \\
\hline Yes & 190 & $0.91(0.55,1.52), 0.121$ & $1.05(0.69,1.60), 0.098$ \\
\hline \multicolumn{4}{|l|}{ Gender } \\
\hline Girls & 171 & $0.95(0.53,1.36)$ & $1.42(0.92,2.10)$ \\
\hline Boys & 217 & $1.46(1.13,2.08)^{*}, 0.039$ & $2.13(1.31,3.45)^{* *}, 0.004$ \\
\hline
\end{tabular}

$\mathrm{OR}(95 \% \mathrm{Cl})$ was estimated for an IQR increase in $\mathrm{PM}_{10}, \mathrm{SO}_{2}, \mathrm{NO}_{2}, \mathrm{CO}$, and $\mathrm{O}_{3}$

${ }^{*} p<0.05$

${ }^{* *} p<0.01$

Adjustment for all the potential covariates in Table 2 including personal factors (sex, birth weight, delivery, feeding, eczema, parental allergy, and stress) and indoor factors (tobacco smoke, new furniture, pets, house redecoration) except for the stratification variables

${ }^{a} p$-value of likelihood ratio test comparing model fit with and without inclusion of interaction terms

showed the same performance. The reason was that the multi-pollutant model produced synergistic or additive effects, which was consistent with other reports on air pollution and childhood allergic diseases $[3,30]$. Therefore, in future research, we need to accurately evaluate the effect and improve the evaluation of the concentrations of pollutants and covariates. The complex sources of exposure may cause $\mathrm{PM}_{2.5}$ and $\mathrm{PM}_{10}$ to be nonspecific pollutants and reduce the correlation. But, this study showed that $\mathrm{PM}_{2.5}$ and $\mathrm{PM}_{10}$ are highly correlated. This aspect may be related to the current main source of air pollution in China is automobile exhaust [10]. On the other hand, it may be because PM can act as an allergen carrier, exacerbating allergic reactions, and smaller particles $\left(\mathrm{PM}_{2.5}\right)$ can enter the respiratory tract of underdeveloped lungs and anatomically smaller peripheral airways more quickly in children $[9,31,32]$. Moreover, in China, heavy metal elements $(\mathrm{S}, \mathrm{Zn}, \mathrm{Cu}$, and $\mathrm{Pb}$ ) account for a large proportion of $\mathrm{PM}_{10}$, while $\mathrm{S}$ and $\mathrm{Pb}$ are relatively enriched in $\mathrm{PM}_{2.5}$ [33]. The difference in chemical compositions of PM may cause different degrees of mucosal damage [9].

Table 7 Conditional logistic regression estimated adjusted odds ratios (aORs) and 95\% confidence intervals (Cls) for associations of allergic rhinitis with air pollutant concentrations, stratified by stress and gender

\begin{tabular}{|c|c|c|c|}
\hline \multirow[t]{3}{*}{ Pollutant } & \multirow[t]{3}{*}{ Quintile } & \multirow{3}{*}{$\begin{array}{l}\text { Stressful family events } \\
\text { No, yes } \\
\text { aOR }(95 \% \mathrm{Cl}) \text {, aOR }(95 \% \mathrm{Cl}) p \text {-value }^{\mathrm{a}}\end{array}$} & \multirow{3}{*}{$\begin{array}{l}\text { Gender } \\
\text { Girls, boys } \\
\text { aOR }(95 \% \mathrm{Cl}) \text {, aOR }(95 \% \mathrm{Cl}) p \text {-value }\end{array}$} \\
\hline & & & \\
\hline & & & \\
\hline \multirow[t]{4}{*}{$\mathrm{PM}_{10}$} & 1 & Reference, reference & Reference, reference \\
\hline & 2 & $0.94(0.81,1.13), 1.70(1.54,1.92)$ & $1.02(0.83,1.30), 1.41(1.01,1.77)$ \\
\hline & 3 & $0.91(0.71,1.28), 1.63(1.41,1.87)$ & $0.95(0.74,1.23), 1.38(1.00,1.65)$ \\
\hline & 4 & $1.07(0.86,1.36), 1.80(1.61,2.02) 0.03$ & $1.11(0.93,1.42), 1.49(1.18,1.82) 0.01$ \\
\hline \multirow[t]{4}{*}{$\mathrm{NO}_{2}$} & 1 & Reference, reference & Reference, reference \\
\hline & 2 & $1.05(0.84,1.31) 1.89(1.52,2.13)$ & $1.23(1.04,1.58), 1.51(1.18,1.95)$ \\
\hline & 3 & $1.16(0.93,1.57) 1.90(1.47,2.25)$ & $1.36(1.17,1.66), 1.78(1.26,2.20)$ \\
\hline & 4 & $1.48(1.03,1.85) 1.98(1.74,2.43) 0.04$ & $1.52(1.21,1.94), 2.10(1.85,2.55) 0.01$ \\
\hline
\end{tabular}

$1=$ below the 25 th percentile, $2=$ between the 25 th and 50th percentiles, $3=$ between the 50th and 75 th percentiles, $4=$ above the 75 th percentile. Adjustment for all the potential covariates in Table 2 including personal factors (sex, birth weight, delivery, feeding, eczema, parental allergy, and stress) and indoor factors (tobacco smoke, new furniture, pets, house redecoration) except for the stratification variables

${ }^{a} p$-value of likelihood ratio test comparing model fit with and without inclusion of interaction terms 
The levels of $\mathrm{O}_{3}$ and $\mathrm{NO}_{2}$ are coupled by chemical bonds. The formation of $\mathrm{O}_{3}$ requires sunlight to consume nitrogen [34]. Thus, especially in areas with heavy traffic, when $\mathrm{NO}_{2}$ exposure is high, $\mathrm{O}_{3}$ exposure is usually low [35-37]. And, $\mathrm{NO}_{2}$ can directly cause inflammation in children's sensitive airways, such as AR [38]. The association between $\mathrm{SO}_{2}$ exposure and the risk of $\mathrm{AR}$ in children is controversial [9]. From the point of view of the decrease of $\mathrm{SO}_{2}$ content or the mixing of multiple pollutants, due to the increase of concentrations in other air pollutants, we cannot fully explain the inconsistent ORs trend of $\mathrm{SO}_{2}$ exposure between the single-pollutant model and the multi-pollutant model. Other pollutants may enhance the corrosiveness of $\mathrm{SO}_{2}$ [39]. In Asia, most previous studies did not show a statistically significant correlation between $\mathrm{SO}_{2}$ concentration and AR prevalence in children. On the contrary, some recent studies showed that $\mathrm{SO}_{2}$ concentration was closely related to the prevalence of AR. The change of this trend may be related to different regions, races, and nationalities $[9,39]$, whereas this debate on the correlation between $\mathrm{SO}_{2}$ and the risk of AR in children may be mainly due to allergen-related or neurogenic complex mechanisms $[40,41]$. The difference between $\mathrm{SO}_{2}$ single exposure and mixed exposure was due to the fine dynamic balance between pro- and anti-apoptotic genes in damaged airway epithelium and undamaged airway epithelium [40]. Unfortunately, we did not detect the related immune indicators including these anti-inflammatory cytokines. Other studies have shown that $\mathrm{SO}_{2}$ exposure in multi-pollutant model (petrochemical exposure) had no or moderate association with children's respiratory diseases [42-44]. Thus, we need to expand the sample size in analyzing the correlation between $\mathrm{SO}_{2}$ and children $\mathrm{AR}$.

Because as the height of the building increases, TRAP exposure will decrease [14]. We chose children living below the 4th floor in order to more accurately estimate the actual situation of TRAP exposure. At the same time, to adjust the misclassification bias from TRAP exposure, we collected every child who did not change the family residence during the observation period, and his/her home was very close to the kindergarten, or did not even go to kindergarten. In addition, we adjusted the statistical model for other sources of children's exposure to TRAP (such as smoking at home).

Respiratory and immune system develop and mature rapidly in early childhood, so TRAP exposure during this sensitive period is more likely to damage children's health $[40,41]$. Thus, we chose the early exposure as the observation window for TRAP exposure to help assess the associations similar to other study, which have shown that in the third trimester and the first year of life, TRAP was more dangerous for asthma, AR, and eczema than exposure later [42]. Moreover, TRAP exposure during early developmental period could trigger AR later (aged 4 years old) [43]. The correlation between TRAP and AR was more obvious in children aged 3-4 years old [3]. Allergic children exposed to TRAP are more likely to develop asthma and allergy than nonallergic children [7, 43]. However, we only found that stress and gender factors may exacerbate the risk of TRAP on AR and did not find the influence of genetic susceptibility on AR. This may be related to the multicollinearity from the two variables (parental allergy history and infant eczema) in this study. A meta-analysis reports that psychological stress will cause pregnant women to continuously secrete cortisol, which in turn increases the risk of asthma and allergy in offspring [44]. This may be due to the differentiation of dominant $\mathrm{T}$ helper 2 (Th2)-biased cell, which causes Th1/Th2 homeostasis imbalance in the immune system $[45,46]$.Thus, stress may increase the risk of TRAP by disrupting the immune response [47-49], even at lower doses of physical exposure to promote adverse consequences [50,51]. Whether there is a difference between gender in the associations between TRAP exposure and respiratory diseases is still controversial. For instance, a French birth cohort study showed that there was a positive association between nitrogen oxides and persistent wheezing in 4-year-old boys [46], while a Swedish study showed similar performance in 4-year-old girls [52]. In addition, a meta-analysis of five birth cohorts showed that $\mathrm{PM}_{2.5}$ exposure was positively correlated with asthma in boys aged 4-5 years [45]. A Chinese similar cohort study showed a positive correlation between TRAP exposure and AR in boys aged 3-6 years [53]. The above gender differences are due to the later appearance of male lung surfactants in newborns. From the prenatal period to the first year after birth, the respiratory tract of boys is narrower than that of girls $[54,55]$.

There are several limitations as follows: First, the small sample size may lead to insufficient power to assess an interaction [56]. In order to reduce the possibility of attributable to chance, the investigation needs to be repeated. Second, although we chose the straight-line distance between family and kindergarten to be less than $400 \mathrm{~m}$, there may still be potential exposure misclassifications. Three, the number of monitoring points was scarce and the land use conditions were ignored; thus, the exposure measurement at fixed monitoring points may lead to exposure bias. Four, although in modern Chinese cities with similar scales and architectural styles, the results of this study could be extrapolated to assess the relationship between air pollution and childhood allergic diseases. But, as a northern city in China, the climate and humanistic characteristics of Shenyang are different from those of southern China, so further research is needed to infer these results. Five, this study only involved outdoor air pollution exposure. But 
because children spend 90\% of their time indoors [57] and the concentration of $\mathrm{PM}_{10}$ and $\mathrm{NO}_{2}$ varies greatly between indoor and outdoor $[58,59]$, it may cause uncertainty in air pollution exposure $[57,58]$. However, at present, urban residents in Shenyang basically use natural gas for cooking, which can reduce indoor smoke and dust pollution; moreover, Chinese families are paying more and more attention to air quality and increasing the time to open windows for ventilation, which also increases outdoor air pollution exposure [10]. It cannot be ignored that Shenyang is a heavily polluted city in the northern of China; we speculate that the serious outdoor air pollution may cover up indoor air pollution [60]. Further work is required to investigate the potential interaction between outdoor or indoor air pollution and AR. Finally, we did not collect full data at $0-1$ year of age and only calculated the 2 years of age to the day of AR diagnosis. This made our study inadequate in the ability to identify the susceptible window of exposure in the development of childhood $A R$ and possible effect modifiers. Thus, the next study should be to investigate the relation of early TARP during pregnancy and the first year of life with the development of AR in later life, and possible effect modifiers.

\section{Conclusion}

Our case-control study supports that family stress and male gender may increase the susceptibility of AR caused by early exposure to TRAP $\left(\mathrm{PM}_{10}\right.$ or $\left.\mathrm{NO}_{2}\right)$ in preschool children aged $2-4$ years.

\section{Abbreviations}

AR: Allergic rhinitis; CO: Carbon monoxide; Cl: Confidence interval; IQR: Interquartile range; $\mathrm{NO}_{2}$ : Nitrogen dioxide; OR: Odds ratio; O3: Ozone; $\mathrm{PM}_{10}$ : Particulate matter less than $10 \mu \mathrm{m}$ in diameter; $\mathrm{SO}_{2}$ : Sulfur dioxide; TRAP: Traffic-related air pollution

\section{Acknowledgements}

We thank the children and their parents for sincere participation and Dr. Yu for estimating individual air pollution exposure.

\section{Authors' contributions}

$\mathrm{XJJ}$ and $\mathrm{AHY}$ conceived and designed the experiments. SH, FY, PP, and BY performed the experiments. $\mathrm{SH}$ analyzed the data and wrote the paper. All authors read and approved the final manuscript.

\section{Funding}

National Natural Science Foundation of China (grant number 81400469)

\section{Availability of data and materials}

The data can be made available from the corresponding author for all interested researchers upon requests sent to the author's office. The initial contact for request should be addressed to the corresponding author's institution.

\section{Declarations}

\section{Ethics approval and consent to participate}

This study was approved by the medical ethics committee of China Medical University [approval number 2013-01-013], and all participants have signed informed consents.
Consent for publication

Not applicable.

\section{Competing interests}

The authors declare that they have no competing interests.

Received: 6 December 2020 Accepted: 4 April 2021

Published online: 17 April 2021

\section{References}

1. Bao Y, Chen J, Cheng L, Guo Y, Hong S, Kong W, et al. Chinese Society of Allergy (CSA) and Chinese Allergic Rhinitis Collaborative Research Group (C2AR2G). Chinese Guideline on allergen immunotherapy for allergic rhinitis. J Thorac Dis. 2017;9(11):4607-50.

2. Mastrorilli C, Posa D, Cipriani F, Caffarelli C. Asthma and allergic rhinitis in childhood: what's new. Pediatr Allergy Immunol. 2016;27(8):795-803.

3. Deng Q, Lu C, Yu Y, Li Y, Sundell J, Norbäck D. Early life exposure to trafficrelated air pollution and allergic rhinitis in preschool children. Respiratory Medicine. 2016;121:67-73.

4. Brożek JL, Bousquet J, Agache I, Agarwal A, Bachert C, Bosnic-Anticevich S, et al. Allergic rhinitis and its impact on asthma (ARIA) guidelines-2016 revision. J Allergy Clin Immunol. 2017:40(4):950-8.

5. $\mathrm{Ng} \mathrm{CL}$, Wang DY. Latest developments in allergic rhinitis in allergy for clinicians and researchers. Allergy. 2015;70(12):1521-30.

6. Brandt EB, Myers JM, Ryan PH, Hershey GK. Air pollution and allergic diseases. Curr Opin Pediatr. 2015;27(6):724-35.

7. Dell SD, Jerrett M, Beckerman B, Brook JR, Foty RG, Gilbert NL, et al. Presence of other allergic disease modifies the effect of early childhood traffic-related air pollution exposure on asthma prevalence. Environ Int. 2014;65:83-92.

8. Wang J, Lu M, An Z, Jiang J, Li J, Wang Y, et al. Associations between air pollution and outpatient visits for allergic rhinitis in Xinxiang. China. Environ Sci Pollut Res Int. 2020;27(19):23565-74.

9. Zou QY, Shen Y, Ke X, Hong SL, Kang HY. Exposure to air pollution and risk of prevalence of childhood allergic rhinitis: a meta-analysis. Int J Pediatr Otorhinolaryngol. 2018;112:82-90.

10. Song C, Wu L, Xie Y, He J, Chen X, Wang T, et al. Air pollution in China: status and spatiotemporal variations. Environ Pollut. 2017;227:334-47.

11. HEl Panel on the Health Effects of Traffic-Related Air Pollution. Traffic-related air pollution: a critical review of the literature on emissions, exposure, and health effects. Boston, MA: Health Effects Institute; 2010.

12. Jung DY, Leem JH, Kim HC, Kim JH, Hwang SS, Lee JY, et al. Effect of trafficrelated air pollution on allergic disease: results of the Children's health and environmental research. Allergy Asthma Immunol Res. 2015;7(4):359-66.

13. Min KD, Yi SJ, Kim HC, Leem JH, Kwon HJ, Hong S, et al. Association between exposure to traffic-related air pollution and pediatric allergic diseases based on modeled air pollution concentrations and traffic measures in Seoul, Korea: a comparative analysis. Environ Health. 2020;19(1):6.

14. Yi SJ, Shon C, Min KD, Kim HC, Leem JH, Kwon HJ, et al. Association between exposure to traffic-related air pollution and prevalence of allergic diseases in children, Seoul, Korea. Biomed Res Int. 2017:2017:4216107.

15. Lee MR, Son BS, Park YR, Kim HM, Moon JY, Lee YJ, et al. The relationship between psychosocial stress and allergic disease among children and adolescents in Gwangyang Bay, Korea. J Prev Med Public Health. 2012:45(6): 374-80

16. Klinnert MD, Nelson HS, Price MR, Adinoff AD, Leung DY, Mrazek DA. Onset and persistence of childhood asthma: predictors from infancy. Pediatrics. 2001:108(4):E69.

17. Sandberg S, Paton JY, Ahola S, McCann DC, McGuinness D, Hillary CR, et al. The role of acute and chronic stress in asthma attacks in children. Lancet. 2000;356(9234):982-7.

18. Wright RJ, Cohen S, Carey V, Weiss ST, Gold DR. Parental stress as a predictor of wheezing in infancy: a prospective birth-cohort study. Am J Respir Crit Care Med. 2002;165(3):358-65.

19. He ZH, Yin WG. Family environments and children's executive function: the mediating role of children's affective state and stress. J Genet Psychol. 2016; 177(5):143-55

20. Ye ZJ, Qiu HZ, Li PF, Liang MZ, Wang SN, Quan XM. Resilience model for parents of children with cancer in mainland China-an exploratory study. Eur J Oncol Nurs. 2017;27:9-16. 
21. Chen E, Hanson MD, Paterson LQ, Griffin MJ, Walker HA, Miller GE. Socioeconomic status and inflammatory processes in childhood asthma: the role of psychological stress. J Allergy Clin Immunol. 2006;117(5):1014-20.

22. Miller GE, Chen E. Life stress and diminished expression of genes encoding glucocorticoid receptor and beta(2)-adrenergic receptor in children with asthma. Proc Natl Acad Sci U S A. 2006;103(14):5496-501.

23. Liu LY, Coe CL, Swenson CA, Kelly EA, Kita H, Busse WW. School examinations enhance airway inflammation to antigen challenge. Am J Respir Crit Care Med. 2002;165(8):1062-7.

24. Wright RJ, Finn P, Contreras JP, Cohen S, Wright RO, Staudenmayer J, et al Chronic caregiver stress and IgE expression, allergen-induced proliferation, and cytokine profiles in a birth cohort predisposed to atopy. J Allergy Clin Immunol. 2004;113(6):1051-7.

25. Lee YL, Shaw CK, Su HJ, Lai JS, Ko YC, Huang SL, et al. Climate, traffic-related air pollutants and allergic rhinitis prevalence in middle-school children in Taiwan. Eur Respir J. 2003;21(6):964-70.

26. Dong $\mathrm{GH}$, Wang J, Zeng XW, Chen $\mathrm{L}$, Qin XD, Zhou Y, et al. Interactions between air pollution and obesity on blood pressure and hypertension in Chinese children. Epidemiology. 2015;26(5):740-7.

27. Hammen C. Generation of stress in the course of unipolar depression. J Abnorm Psychol. 1991;100(4):555-61.

28. Hosmer DW, Lemeshow S. Applied logistic regression. New York: Wiley; 1989.

29. Schisterman EF, Cole SR, Platt RW. Over-adjustment bias and unnecessary adjustment in epidemioloic studies. Epidemiology. 2009;20(4):488-95.

30. Deng Q, Lu C, Li Y, Sundell J, Norbäck D. Exposure to outdoor air pollution during trimesters of pregnancy and childhood asthma, allergic rhinitis, and eczema. Environ Res. 2016;150:119-27.

31. Lee SW, Yon DK, James CC, Lee S, Koh HY, Sheen YH, et al. Short-term effects of multiple outdoor environmental factors on risk of asthma exacerbations: age-stratified time-series analysis. J Allergy Clin Immunol. 2019;144(6):1542-50

32. Wang $M$, Aaron CP, Madrigano J, Hoffman EA, Angelini E, Yang J, et al Association between long-term exposure to ambient air pollution and change in quantitatively assessed emphysema and lung function. JAMA 2019;322(6):546-56.

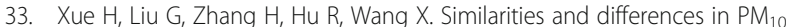
and $\mathrm{PM}_{2.5}$ concentrations, chemical compositions and sources in Hefei City, China. Chemosphere. 2019;220:760-5.

34. Clapp $\sqcup$, Jenkin ME. Analysis of the relationship between ambient levels of $\mathrm{O}_{3}, \mathrm{NO}_{2}$ and $\mathrm{NO}$ as a function of $\mathrm{NO}_{x}$ in the UK. Atmos Environ. 2001;35(36): 6391-405.

35. Jerrett M, Arain A, Kanaroglou P, Beckerman B, Potoglou D, Sahsuvaroglu T, et al. A review and evaluation of intraurban air pollution exposure models. J Expo Anal Environ Epidemiol. 2005;15(2):185-204.

36. Lipsett MJ, Ostro BD, Reynolds P, Goldberg D, Hertz A, Jerrett M, et al. Longterm exposure to air pollution and cardiorespiratory disease in the California teachers study cohort. Am J Respir Crit Care Med. 2011;184(7):828-35.

37. Smith GS, Van Den Eeden SK, Garcia C, Shan J, Baxter R, Herring AH, et al. Air pollution and pulmonary tuberculosis: a nested case-control study among members of a northern California health plan. Environ Health Perspect. 2016;124(6):761-8.

38. Peden DB. Mechanisms of pollution-induced airway disease: in vivo studies. Allergy. 1997;52(38 Suppl):37-44.

39. World Health Organization. Air quality guidelines: global update 2005: particulate matter, ozone, nitrogen dioxide and sulfur dioxide. Geneva: World Health Organization; 2006.

40. Abdulamir AS, Hafidh RR, Abubakar F, Abbas KA. Changing survival, memory cell compartment, and T-helper balance of lymphocytes between severe and mild asthma. BMC Immunol. 2008;9:73.

41. Reno AL, Brooks EG, Ameredes BT. Mechanisms of heightened airway sensitivity and responses to. inhaled $\mathrm{SO}_{2}$ in asthmatics. Environ Health Insights. 2015;9(Suppl 1):13-25.

42. Rusconi F, Catelan D, Accetta G, Peluso M, Pistelli R, Barbone F, et al. Asthma symptoms, lung, function, and markers of oxidative stress and inflammation in children exposed to oil refinery pollution. J Asthma. 2011; 48(1):84-90.

43. Lee SL, Wong WHS, Lau YL. Association between air pollution and asthma admission among children in Hong Kong. Clin Exp Allergy. 2006:36(9):1138-46.

44. Flanigan C, Sheikh A, DunnGalvin A, Brew BK, Almqvist C, Nwaru BI. Prenatal maternal psychosocial stress and offspring's asthma and allergic disease: a systematic review and meta-analysis. Clin Exp Allergy. 2018;48(4):403-14.
45. Bowatte G, Lodge C, Lowe AJ, Erbas B, Perret J, Abramson MJ, et al. The influence of childhood traffic related air pollution exposure on asthma, allergy and sensitization: a systematic review and a meta-analysis of birth cohort studies. Allergy. 2015;70(3):245-56.

46. Rancière F, Bougas N, Viola M, Momas I. Early exposure to traffic-related air pollution, respiratory symptoms at 4 years of age, and potential effect modification by parental allergy, stressful family events, and sex: a prospective follow-up study of the PARIS birth cohort. Environ Health Perspect. 2017;125(4):737-45.

47. Chen E, Schreier HM, Strunk RC, Brauer M. Chronic traffic-related air pollution and stress interact to predict biologic and clinical outcomes in asthma. Environ Health Perspect. 2008;116(7):970-5.

48. Wright RJ. Psychological stress: a social pollutant that may enhance environmental risk. Am J Respir Crit Care Med. 2011;184(7):752-4.

49. Emin O, Hasan A, Aysegul D, Rusen D. Total antioxidant status and oxidative stress and their relationship to total lgE levels and eosinophil counts in children with allergic rhinitis. J Investig Allergol Clin Immunol. 2012;22(3): 188-92.

50. Mölter A, Simpson A, Berdel D, Brunekreef B, Custovic A, Cyrys J, et al. A multicentre study of air pollution exposure and childhood asthma prevalence: the ESCAPE project. Eur Respir J. 2015;45(3):610-24.

51. Celik M, Tuncer A, Soyer OU, Saçkesen C, Tanju Besler H, Kalayci O. Oxidative stress in the airways of children with asthma and allergic rhinitis. Pediatr Allergy Immunol. 2012;23(6):556-61.

52. Nordling E, Berglind N, Melén E, Emenius G, Hallberg J, Nyberg F, et al. Traffic-related air pollution and childhood respiratory symptoms, function and allergies. Epidemiology. 2008;19(3):401-8.

53. Deng Q, Lu C, Norbäck D, Bornehag CG, Zhang Y, Liu W, et al. Early life exposure to ambient air pollution and childhood asthma in China. Environ Res. 2015;143(Pt A):83-92.

54. Wright RJ, Brunst KJ. Programming of respiratory health in childhood: influence of outdoor air pollution. Curr Opin Pediatr. 2013;25(2):232-9

55. Carey MA, Card JW, Voltz JW, Arbes SJ Jr, Germolec DR, Korach KS, et al. It's all about sex: gender, lung development and lung disease. Trends Endocrinol Metab. 2007;18(8):308-13.

56. Knol MJ, VanderWeele TJ. Recommendations for presenting analyses of effect modification and interaction. Int J Epidemiol. 2012;41(2):514-20.

57. Deng Q, Lu C, Jiang W, Zhao J, Deng L, Xiang Y. Association of outdoor air pollution and indoor renovation with early childhood ear infection in China. Chemosphere. 2017;169:288-96.

58. Adgate JL, Ramachandran G, Pratt GC, Waller LA, Sexton K. Spatial and temporal variability in outdoor, indoor, and personal $\mathrm{PM}_{2.5}$ exposure. Atmos Environ. 2002:36(20):3255-65.

59. Edwards RD, Jurvelin J, Saarela K, Jantunen M. VOC concentrations measured in personal samples and residential indoor, outdoor and workplace microenvironments in EXPOLIS-Helsinki. Finland. Atmos Environ. 2001;35(27):4531-43.

60. Myers I, Maynard RL. Polluted air-outdoors and indoors. Occup Med (Lond). 2005;55(6):432-8.

\section{Publisher's Note}

Springer Nature remains neutral with regard to jurisdictional claims in published maps and institutional affiliations.

Ready to submit your research? Choose BMC and benefit from:

- fast, convenient online submission

- thorough peer review by experienced researchers in your field

- rapid publication on acceptance

- support for research data, including large and complex data types

- gold Open Access which fosters wider collaboration and increased citations

- maximum visibility for your research: over $100 \mathrm{M}$ website views per year

At $\mathrm{BMC}$, research is always in progress.

Learn more biomedcentral.com/submission 